\title{
Prevalence and risk factors of diabetes mellitus in the rural region of Mali (West Africa): a practical approach
}

\author{
A. Fisch ${ }^{1}$, E. Pichard ${ }^{3}$, T. Prazuck ${ }^{1}$, H. Leblanc ${ }^{2}$, Y. Sidibe ${ }^{3}$ and G. Brücker ${ }^{1}$ \\ ${ }^{1}$ Institut Santé et Développement, and ${ }^{2}$ Service de Nutrition Endocrinologie, Hôpital Saint-Louis, Paris, France; \\ ${ }^{3}$ Service de Médecine Interne, Hôpital du Point G, Bamako, Mali
}

Summary. A wide-range analytical study for screening diabetes mellitus in the rural region of the Republic of Mali was carried out on 7,472 subjects in whom fasting glycaemia was determined using reflectometry kits. Our results represent a breakthrough in the field of epidemiology of diabetes mellitus in West Africa. The prevalence rate of fasting hyperglycaemia equal to or over $7.00 \mathrm{mmol} / 1$ was $0.92 \%$. The statistical analysis of data collected in this manner showed an increased prevalence in the Caucasian and Fulani ethnic groups, and a decreased prevalence in the Negroid ethnic groups. Age and body mass index are also risk factors in this population.

Key words: Hyperglycaemia, diabetes mellitus, Africa, epidemiology.
To our knowledge, no epidemiological study of diabetes mellitus has been conducted in West Africa according to WHO criteria [1]. Between May 1984 and May 1985, we undertook a wide-range epidemiological study of 7,472 subjects in the rural region of Mali. We found that the prevalence rate of the subjects who exhibited fasting hyperglycaemia equal to or over $7.00 \mathrm{mmol} / 1$ was $0.92 \%$; it is a low rate compared to the prevalence rate of diabetes mellitus in industrialised countries; however, some ethnic groups showed a higher risk for diabetes.

\section{Subjects and methods}

Mali is a country in West Africa with a Sudanese-Sahelian climate. According to the official reports of the Malian Ministry of Planning, the population was $7,642,519$ inhabitants $(95.4$ males for $100 \mathrm{fe}$ males) on 1 January 1985 [3]; the rural population was estimated at $6,315,802$ subjects; $54 \%$ of Malians are under 20 years old.

The study was carried out on all subjects over 15 years of age from villages selected at random using the cluster method. The number of subjects required had been estimated as 5,059. The day before the examination the investigators informed the population in each village of the aim of the study and demonstrated that the tests were harmless. The survey team did not visit the villages during any intensive agricultural period. All subjects were asked to fast and the following parameters were determined: age, sex, ethnic group, height, weight, left arm circumference, religion, occupation; a finger-tip sample of blood was taken for the glycaemia determination. Age was determined by interview and from the official census. However, for Malians over 30 years old, the age is often given to the nearest multi- ple of five. Table 1 shows the profession of the study subjects and the levels of energy expenditure. The subjects were weighed with scales which were regularly recalibrated (margin of error: $1 \mathrm{~kg}$ ). The subjects were measured barefoot using a yardstick made of a wooden horizontal plate. The body mass index was calculated from these data as the ratio of weight to height in meters squared. The arm circumference was measured on the left arm, half bent, half way between the acromion and olecranon with an undeformable plastic band.

Glycaemia was measured by reflectometry with Reflolux (Boehringer Mannheim GmbH, Mannheim, FRG) and Glucometer (Ames Miles) analysers. In a former study carried out under tropical conditions, we demonstrated that the correlation coefficient between this

Table 1. Occupation and daily energy expenditure in the study population

\begin{tabular}{lll}
\hline Occupation & $\begin{array}{l}\text { Level of daily } \\
\text { energy expenditure }\end{array}$ & Number \\
\hline $\begin{array}{l}\text { Farmers } \\
\text { Farmers' wives, }\end{array}$ & $\begin{array}{l}\text { High } \\
\text { (Group I) }\end{array}$ & 6139 \\
$\begin{array}{l}\text { Administrative staff } \\
\text { Craftsmen, } \\
\text { Village chief }\end{array}$ & $\begin{array}{l}\text { Medium } \\
\text { (Group II) }\end{array}$ & 1045 \\
$\begin{array}{l}\text { Matrons } \\
\text { Merchants }\end{array}$ & & \\
$\begin{array}{l}\text { Teachers } \\
\text { School children } \\
\text { Marabouts } \\
\text { Seconds } \\
\text { Handicapped people }\end{array}$ & & \\
\hline
\end{tabular}


Table 2. Prevalence rate and odds ratio of diabetes according to age

\begin{tabular}{llllll}
\hline Age (years) & $\begin{array}{l}\text { Number of } \\
\text { diabetic patients }\end{array}$ & $\begin{array}{l}\text { Number without } \\
\text { diabetes }\end{array}$ & Prevalence rate & Odds ratio \\
\hline $15-24$ & 10 & 2548 & $0.39 \%(0.29-0.49)$ & 1 & \\
$25-34$ & 8 & 1787 & $0.44 \%(0.24-0.44)$ & $1.14(0.41-3.13)$ \\
$35-44$ & 10 & 1237 & $0.80 \%(0.50-1.10)$ & $2.06(0.79-5.35)$ & NS \\
$45-54$ & 16 & 885 & $1.77 \%(1.37-2.17)$ & $4.60(1.96-10.94)$ & $p<0.01$ \\
$55-64$ & 14 & 606 & $2.26 \%(1.66-2.86)$ & $5.80(2.44-14.32)$ & $p<0.01$ \\
$>65$ & 11 & 340 & $3.23 \%(1.93-7.26)$ & $8.24(3.23-21.10)$ & $p<0.001$ \\
\hline
\end{tabular}

Table 3. Means of body mass index according to age among diabetic patients

\begin{tabular}{|c|c|c|c|c|}
\hline $\begin{array}{l}\text { Age } \\
\text { (years) }\end{array}$ & $\begin{array}{l}\text { Number } \\
\text { of male } \\
\text { subjects }\end{array}$ & $\begin{array}{l}\text { Number } \\
\text { of female } \\
\text { subjects }\end{array}$ & $\begin{array}{l}\text { Body mass } \\
\text { index } \\
\text { (male) }\end{array}$ & $\begin{array}{l}\text { Body mass } \\
\text { index } \\
\text { (female) }\end{array}$ \\
\hline$<20$ & 2 & 4 & $\begin{array}{l}19.2 \\
(15.9-22.24)\end{array}$ & $\begin{array}{l}25.9 \\
(23.6-29.2)\end{array}$ \\
\hline $20-29$ & 2 & 8 & $\begin{array}{l}20.5 \\
(19.6-21.4)\end{array}$ & $\begin{array}{l}26.2 \\
(21.0-32.9)\end{array}$ \\
\hline $30-39$ & 2 & 6 & $\begin{array}{l}26.2 \\
(17.3-35.2)\end{array}$ & $\begin{array}{l}31.1 \\
(23.2-43.8)\end{array}$ \\
\hline $40-49$ & 4 & 11 & $\begin{array}{l}23.7 \\
(17.7-29.0)\end{array}$ & $\begin{array}{l}28.5 \\
(20.3-41.6)\end{array}$ \\
\hline $50-59$ & 8 & 5 & $\begin{array}{l}21.4 \\
(16.9-28.4)\end{array}$ & $\begin{array}{l}27.2 \\
(19.7-37.8)\end{array}$ \\
\hline $60-69$ & 8 & 5 & $\begin{array}{l}21.4 \\
(16.3-36.7)\end{array}$ & $\begin{array}{l}25.2 \\
(19.7-33.4)\end{array}$ \\
\hline$\geq 70$ & 2 & 2 & $\begin{array}{l}24.1 \\
(19.4-28.7)\end{array}$ & $\begin{array}{l}29.1 \\
(28.5-29.6)\end{array}$ \\
\hline
\end{tabular}

reflectometric method and the reference method (God-Pap, Boehringer-Mannheim $\mathrm{GmbH}$ ) was 0.993 [2].

Subjects were considered as diabetic patients, according to international standards [1], when fasting glycaemia was equal to, or over $7.00 \mathrm{mmol} / 1$ in two successive tests; the second test, carried out on average $1 \mathrm{~h}$ after the first, confirmed hyperglycaemia in $100 \%$ of the cases. Thirty-two subjects were excluded because they had not fasted (first interrogation by interviewer: 28 subjects excluded; second interrogation by traditional chief: 4 subjects excluded). The analysed population included 3,481 men and 3,991 women, corresponding to the assumed sex ratio for Mali [3]. Likewise the proportion of different ethnic groups was representative of the rural Malian population [3]: Bambara (2,451 subjects), Bobo (55), Bozo (355), Dogon (33), Malinke (599), Moor (28), Minianka (1,207), Mossi (33), Fulani (611), Sarakole (379), Sonrai (1,671), Tuareg (42), Wolof (8).

The ethnic groups were then classified into five different peoples according to Murdoch [4]: Nuclear Mande (Bambara, Bozo, Malinke, Sarakole), Voltaic Peoples (Bobo, Dogon, Minianka, Mossi), Sonrai, Fulani, Hamitic and Semitic Peoples (Moor and Tuareg). The last group belongs to the Caucasian race; the first three to the Negroid race; the racial origin of the Fulanis is debatable: many authors consider that this is an intermediate race or perhaps Caucasian [4-6]. The Wolof ethnic group was not used for the inter-ethnic statistical analysis, because of its small size $(n=8)$ and because it does not belong to the above mentioned groups.

\section{Statistical analysis}

The data were analysed by VAX780 computer with the BMDP program. The significance of estimates was given by the $95 \%$ approximate confidence interval $(\mathrm{CI})$ around the ratio. The odds ratio was calculated using as a reference the population which exhibited the least prevalence.

The odds ratio Cl's were calculated using the Cornfield method. In order to calculate the trend test, we attributed an equal importance to each group. Multivariate analysis was comprised of a stepwise logistic regression; in order to study the adjusted prevalence of diabetes in the various ethnic groups, we carried out a direct standardisation according to age and weight. The reference population was the whole sample of 7,472 subjects.

\section{Results}

The overall prevalence of fasting hyperglycaemia (equal to or over $7.00 \mathrm{mmol} / \mathrm{l}$ ) was $0.92 \%$.

The glycaemia of non-diabetic subjects, normally distributed, was $4.49 \mathrm{mmol} / 1 \pm 1.05$ (mean $\pm \mathrm{SD}$ ). The mean glycaemia of diabetic subjects was 9.16 (range: 7.00-18.70).

The mean age was 34.3 years (range: $15-102$ ) for non-diabetic subjects and 48.1 years (range: 16-99) for diabetic patients. Table 2 shows the number of subjects, the prevalence and the odds ratio of diabetes according to age. There is a significant linear relationship between age and diabetic risk $(p<0.0001)$.

The diabetic population was found to be 27 men and 42 women ( $M: F$ sex ratio: 0.64$)$ : the difference was not statistically significant. The mean height was $164.8 \mathrm{~cm}(\mathrm{SD}=9.05)$ for non-diabetic subjects and $165.1 \mathrm{~cm}(\mathrm{SD}=7.89)$ for diabetic patients: the difference is not statistically significant $(p>0.05)$.

Table 3 shows the means of body mass index according to age among diabetic patients.

The mean body mass index was 23.1 (range: 8.9-51.8) for non-diabetic subjects, and 25.4 (range: 15.9-43.9) for diabetic patients: the difference is statistically significant. Table 4 shows the means of body mass index according to age among diabetic patients.

Among the diabetic women, 3 were pregnant $(8.57 \%)$; among the non-diabetic women, 266 were pregnant $(6.66 \%)$ : the difference is not statistically significant (Chi $2=0.52, p>0.05$ ).

Of the 7,472 subjects, 7,340 were Moslem, and 97 were Christian. We did not observe hyperglycaemia among the subjects of Christian faith but, given the overall prevalence rate $(0.92 \%)$, this does not enable any conclusion to be drawn.

No significant difference was observed between 
Table 4. Prevalence rate and odds ratio of diabetes according to body mass index

\begin{tabular}{llllll}
\hline Body mass index & $\begin{array}{l}\text { Number of } \\
\text { diabetic patients }\end{array}$ & $\begin{array}{l}\text { Number without } \\
\text { diabetes }\end{array}$ & $\begin{array}{l}\text { Prevalence } \\
\text { rate }(\%)\end{array}$ & $p$ \\
\hline$<21$ & 18 & 2635 & $0.68(0.56-0.80)$ & 1 & \\
$21.0-24.9$ & 21 & 2511 & $0.83(0.71-0.95)$ & $1.22(0.62-2.40)$ & NS \\
$25.0-26.9$ & 5 & 976 & $0.51(0.27-0.75)$ & $0.75(0.24-2.14)$ & NS \\
$27.0-28.9$ & 8 & 642 & $1.23(0.95-1.51)$ & $1.82(0.79-4.16)$ & NS \\
$\geq 29$ & 17 & 639 & $2.59(2.30-2.88)$ & $3.89(2.09-7.25)$ & $p<0.0001$ \\
\hline
\end{tabular}

Table 5. Standardised prevalence of diabetes according to ethnic group

\begin{tabular}{lllll}
\hline & $\begin{array}{l}\text { Number of } \\
\text { subjects with } \\
\text { glycaemia } \\
<7.00 \mathrm{mmol} / 1\end{array}$ & $\begin{array}{l}\text { Number of } \\
\text { subjects with } \\
\text { glycaemia } \\
\geq 7.00 \mathrm{mmol} / 1\end{array}$ & $\begin{array}{l}\text { Standardised } \\
\text { prevalence } \\
\text { rate }\end{array}$ & $p$ \\
\hline Sonrai & 1657 & 14 & $\begin{array}{l}0.66 \\
(0.36-1.08)\end{array}$ & \\
& & & 0.69 & NS \\
Voltaic & 1320 & 8 & $(0.23-1.13)$ & \\
people & & 31 & 0.78 & NS \\
Nuclear & 3754 & & $(0.49-1.04)$ & \\
mande & & 14 & 2.27 & $p<0.01$ \\
Fulani & 594 & & $(1.10-3.48)$ & \\
& & 3 & 2.46 & $p<0.05$ \\
Hamito- & 67 & & $(0.85-9.42)$ & \\
semitic & & & & \\
\hline
\end{tabular}

diabetic and non-diabetic subjects according to their level of activity when this was adjusted on age.

We attempted to determine whether hyperglycaemia was more frequent in certain months or seasons throughout our study. No significant difference was found.

To estimate the relationship between ethnic groups and diabetic risk, we carried out a stepwise logistic regression. Adjusted by age and weight, belonging to the Fulani ethnic group and to the Hamito-semitic group constitutes a diabetic risk factor $(p=0.01)$. Because of the lack of correlation between age and weight $(r=0.11)$, in order to estimate the real prevalence of diabetes in each ethnic group, we carried out a direct standardisation according to age and weight using the whole population as the reference population. Table 5 indicates the observed number of subjects and the standardised prevalence rate in each ethnic group. The Fulani and Hamito-semitic groups appear to be significantly more affected by diabetes.

\section{Discussion}

This epidemiological study has enabled us to calculate the prevalence of fasting hyperglycaemia according to the WHO criteria among rural Africans, i.e. the majority of the population [3]. The figure of $0.92 \%$ indicates the prevalence of diabetes mellitus only by default, since the measurement of glycaemia $2 \mathrm{~h}$ after oral ingestion of $75 \mathrm{~g}$ of glucose was not carried out. Nevertheless, to our knowledge, this is the first attempt to determine the prevalence of this disease in Black Africa. The lack of statistical data $[1,7]$ has led to much debate about the prevalence of diabetes mellitus in the $\mathrm{Ne}$ groid race. Many years ago, most authors assumed that diabetes mellitus did not exist in Black Africa [8]. Later, studies in urban areas and hospitals indicated a prevalence similar to that observed in Europe and North America [7, 9]. Our study shows that diabetes mellitus does exist among Black Africans, but at a lower prevalence than that observed in industrialised countries.

Our study shows that weight, body mass index and age are strong risk factors of diabetes in our African population as is the case in the Caucasian race. Moreover, we found evidence of an ethnic risk factor in this population: the most obvious Caucasian ethnic groups (Tuareg, Moor) show the highest prevalence, and the Negroid ethnic groups (Sonrai, Voltaic, Mande) show the lowest; the Fulanis, whom some authors [5] consider as being of Judeo-Syrian origin, are an intermediary ethnic group. Our results are compatible with this, for we find no statistically significant difference with regard to hyperglycaemia between the Caucasian and the Fulani groups.

We could not interview each subject about diet and so we could not analyse the existence of nutritional factors. But in Mali, there is no cassava production and the alimentary fibers, carbohydrates and milk product consumption do not seem to show any disparity in the country [10].

It is thus possible that genetic factors intervene, predisposing to or protecting against the occurrence of diabetes in the heart of African populations, an occurrence which is much more clear-cut than that encountered in occidental countries. Studies of genetic typing seem to us to be both appropriate and necessary, in order to understand more clearly this surprising inequality with regard to the occurrence of diabetes mellitus in Africa.

Acknowledgements. The authors wish to acknowledge the Departement de Statistiques (Prof. Flamant), Institut G. Roussy, Villejuif (France); Dr. Derocque, Boehringer Mannheim GmbH, Mannheim (FRG), and Ms. J. Alix for correcting the English manuscript. 


\section{References}

1. World Health Organization (1985) Diabetes mellitus. Monograph Series No 727, Geneva

2. Fisch A, Cisse H, Sidibe Y, Leblanc H, Pichard E (1986) Evaluation du fonctionnement d'un micro-analyseur glycémique dans des conditions climatiques africaines. Med Afr Noire 33: $751-753$

3. Ministère du Plan. République du Mali (1984) Guide d'identification des problèmes de population et des variables démographiques à intégrer dans les plans et les programmes de développement de la République du Mali. Direction nationale de la planification, Bamako

4. Murdoch GE (1959) Africa: its people and their culture and history. McGraw-Hill, New York

5. Delafosse M (1972) Haut-Sénégal-Niger Tome I: les pays, les peuples, les langues. Maisonneuve et Larose, Paris

6. Richard-Molard J (1949) Afrique occidentale française. BergerLevrant, Paris
7. Sankale M, Fabre S, Signate S, Sow AM (1968) Le diabète, maladie sociale au Sénégal. Med Afr Noire 8-9: 341-343

8. Tulloch JA (1962) Diabetes mellitus in the tropics. Livingstone, Edinburgh London

9. Imperato PJ, Handelsman MB, Fofana B, Sow O (1976) The prevalence of diabetes mellitus in three population groups in the Republic of Mali. Trans R Soc Trop Med Hyg 70: 155

10. Sankale M, Satge P, Toury J, Vuylsteke J (1974) Les aliments africains. In: Alimentation et pathologie nutritionnelle en Afrique Noire. Maloine, Paris

Received: 5 March 1987

and in revised form: 9 September 1987

Dr. A. Fisch

Institut Santé et Développement

15-21, rue de l'Ecole de Médecine

F-75270 Paris Cedex 06

France 